\title{
The Conservation of Old Johar Market Building
}

\author{
R. Siti Rukayah ${ }^{1}$, Agung Budi Sardjono', \\ Muhammad Abdullah'2, Annica Etenia ${ }^{1}$ \\ 1 Engineering Faculty, Diponegoro University, Indonesia \\ 2 Cultural Science Faculty, Diponegoro University, Indonesia \\ sitirukayah.tutut@gmail.com, agungbsardjono@gmail.com, abdullahabah47@gmail.com, \\ annicaetenia94@gmail.com \\ Tel: +628122812825
}

\begin{abstract}
The conservation efforts for heritage architecture are currently trending. This paper aims to uncover the conservation of traditional markets after experiencing a fire in the Johar market, Semarang, Central Java, Indonesia. After the market was renovated, it turned out that it had not included all traders in it. Using the historical method, there is revealing that the number of traders exceeds the room's capacity. Theory discusses about the conservation approach and applied adaptive reuse theory found that the initial plan, is possible to return its function as a market by adjusting the number of traders' capacity. The advantages of traders are recommended to occupy the old square area as open spaces to be attractive for heritage tourism.
\end{abstract}

Keywords: conservation, buildings and historical areas, markets, Semarang city

eISSN 2514-751X @ 2020 The Authors. Published for AMER ABRA cE-Bs by e-International Publishing House, Ltd., UK. This is an open access article under the CC BY-NC-ND license (http://creativecommons.org/licenses/bync-nd/4.0/). Peer-review under responsibility of AMER (Association of Malaysian Environment-Behaviour Researchers), ABRA (Association of Behavioural Researchers on Asians / Africans / Arabians) and cE-Bs (Centre for Environment-Behaviour Studies), Faculty of Architecture, Planning \& Surveying, Universiti Teknologi MARA, Malaysia.

DOI: https://doi.org/10.21834/ajebs.v5i17.375 


\subsection{Introduction}

Conservation is an action or effort to prevent damage and extend the life of an old building or historical area. According to the Burra Charter (ICOMOS), the purpose of conservation must maintain, repair or show as many historical traces as possible on a historical object, whether it is a building or an artifact. Also included in the conservation goals are security, maintenance, and a future for these historical objects and areas. (Australian ICOMOS Inc., 2012) Three criteria can be used to determine whether a building or environment is suitable for conservation, for example, architectural, historical, and symbolic criteria ("Mengembalikan Identitas Kota Pusaka," 2015). Johar Market is one of the historical buildings in Semarang, Central Java, which has these three criteria. Thomas Karsten, a Dutch architect, built Johar Market in the 1930s. Symbolically, the market with a mushroomshaped structure was one of the largest markets in Asia at its time.

This paper aims to reveal building conservation efforts at the Johar traditional market after the market caught fire in 2015. Historical and grounded research methods were carried out to find the types of traders to accommodate the renovated buildings. After researching the study of architectural systems at the market, it is recommended to maintain the authenticity and authenticity of the Johar Market building by Thomas Karsten so that it does not lose the identity of the historic building. (Tjandra, 2019). These conservation efforts were completed in 2019 in the northern zone. The central zone and the south will be carried out later. The problem that arises is that the conservation results of buildings cannot accommodate all traders. This is because only in part of the whole area (northern zone) has been revitalized. The placement of old traders to go back into the building is a dilemma for the government. The buildings that have been conserved are still empty. Thus, it is necessary to think of a new function for the renovated Johar Market building's northern zone.

In the aspect of building arrangement, the Directorate General of Human Settlements, through the Heritage City Structuring and Conservation Program (P3KP), encourages the management of Heritage Areas to restore their identity and prevent new slum areas due to urbanization, especially heritage areas that need to be preserved because the heritage city has important values of own identity / national identity, historical, environmental, social, political, and so on optimally ("Mengembalikan Identitas Kota Pusaka," 2015). To develop a sustainable historical area, it is necessary to have sustainable organizational, management, and financial structures, accompanied by leadership and commitment to the regeneration projects from political authorities, especially districts and metropolitan municipalities (Ercan, 2016). The City Government plays a significant role in determining the success of heritage architectural preservation. Through this agency, guidance is needed in controlling the heritage architectural design process in the aspect of change, color handling, additions to the facade, building height, and other aspects (Adishakti, 2009).

Semarang has traces of the history of the pre-colonial city to the colonial era. Besides that, Semarang has its zone with the center of the local government (R. S. Rukayah \& Malik, 2012). Remains in the colonial era along the canals and fortresses are traces of the city that Semarang once had its glory as a VOC trading city. The Semarang city government 
has carried out the arrangement of the Old City Semarang area, which was carried out since 2017 and was completed in April 2019. The Old City Semarang area arrangement aims to make the city of Semarang a liveable and sustainable heritage city. Apart from Old City Semarang, the PUPR Ministry is also revitalizing Johar Market, a historical building for Semarang. The revitalization was carried out after the 2015 fire, which burned down twothirds of the market building. The rebuilding will begin in 2019, with an estimated cost of IDR 174.12 billion.

As a cultural heritage area, market activity is an important part of a city's economic growth. Its existence is a reflection of a city with historical and economic value for urban development. High strategic value and still hidden, this area can also be called the golden area or gold mining area (Budihardjo, 1997). Economically, the Johar market accommodates around 6,000 traders (Setiaji \& Fatuniah, 2018). When the market caught fire, traders temporarily moved to the Central Java Grand Mosque (MAJT) area on arterial path Soekarno-Hatta. After conservation efforts for the northern part of the zone, which is still empty, what activities are appropriate to occupy it?

\subsection{Literature Review}

Conservation is a term that is the umbrella for all conservation activities under international agreements that have been formulated in the 1981 Burra Charter, "The Burra Charter for the Conservation of Place of Cultural Significance". (Australian ICOMOS Inc., 2012) In carrying out the work of conservation of historical buildings, it is necessary to have a global approach so that something presented as a 'Message Value' can be conveyed according to the authenticity of the building's architecture. It can be seen that conservation planning is of great significance to the protection of traditional villages and historic villages (Luo \& Qi, 2020). With conservation it will promote more effective protection of cultural heritage sites (Luo \& Qi, 2019). Conservation also might be used with different concepts (Wang \& $\mathrm{Fu}, 2014)$. Adaptive reuse theory introduces several methods in revitalization activities, based on Bollack (2013), He explains about five types of adaptive reuse, and the types are classified based on the pattern of changes by naming them as 'insertions', 'parasites', 'wraps', 'juxtapositions', 'weavings' and so on. Adaptive reuse is a method of preserving cultural heritage buildings, which can rehabilitate buildings and historical areas by maintaining construction, facades, and ornaments. (Pongsermpol \& Upala, 2018). Adaptive reuse shows from all aspects, including the holistic, integrative making of social, economic, environmental, urban, and political policies (Yung \& Chan, 2012). Also, adaptive reuse is an activity in changing damaged historic buildings to accommodate the current needs of new users and environmentally friendly uses (Latham, 2016) and regarding the public value of historical assets (Jang et al., 2017). The adaptive reuse converts abandoned buildings into functional and usable spaces while also increasing the value of the building itself (Bullen \& Love, 2011). 


\subsection{Methodology}

Based on the definition of adaptive reuse above, namely how buildings are conserved to accommodate the current needs and new users, the research theory uses conservation theory and applied adaptive reuse theory. The Johar market is a historical building that was formerly a trading center in the colonial period. This study applies a descriptive qualitative method and then ends by discussing the Johar Market building first, after the fire, until now after conservation in 2019 so that we can find out the process of building Johar Market until now. By conducting several studies to know some of the shortcomings of revitalization activities, architecture in conservation is a form that describes human activities and how they live, not only by memories of the past (Zonta et al., 2008) (Musso \& Loughlin, 2011).

To get the old data, the author used historical method to get old literature and then continuing by conducting field observation. The data that has been obtained then analyzed using the descriptive analysis method. The descriptive analysis method is a method that uses data explanation in the form of the condition of the research object that has been obtained through the results of field surveys, namely observations and interviews. To find out the revitalization of Johar's building, the author conducted a descriptive analysis to determine the conditions in the Johar market building and classified types of adaptive reuse used. The disadvantage of the method that has been used is the ability to get old data on the number of traders and trader data before the market burns. Comparing the two is significant to find that the market conditions after 90 years of existence have over-sized tamping power.

\subsection{Analysis and Finding}

\subsection{Cultural Heritage}

Johar Market is the largest traditional market in Semarang City. This market is located in a trading area in Semarang City, precisely near the old square area of Semarang City. Market Bulu, Market Peterongan, and Johar Market are at each end of the old golden triangle and work in the same space as modern shops' growth along the three corridors. (S. Rukayah \& Supriadi, 2017). The Johar Market building itself has a land area of $\pm 17,225 \mathrm{~m} 2$, the Johar Market area, which includes the Kanjengan site, and traditional square is an heirloom area that has the potential to have a strong enough influence on the physical building development of the area and its surroundings. However, the condition of Johar Market is still apprehensive because there are no supporting facilities and adequate comfort factors (Rahayu et al. 2015).

According to the book BAPPEDA Kota Semarang (2006), started a century ago in 1860. Many traders held their wares in detention at that time, waiting for visiting hours under Johar's tree. According to the story, the Johar tree was a gift from Sunan Pandanaran, who did not want the area to be slummed by the traders' tents. Therefore, Sunan Pandanaran ordered to plant Johar trees around the prison location to be used for shelter. Goods sold by traders are agricultural products such as fruit, corn, bananas, and also cassava. At that 
time, the traders did not interfere with traffic, so the local government alone. Only the cleaning staff collect fees from the traders. Johar Market is becoming increasingly congested and requires expansion of space. After going through the assessment process, finally, the Johar market was expanded by cutting down Johar trees and building new booths. In 1931 the old prison building near Johar Market was demolished to connect with the municipal government's plan to establish Central Modern. The market was then established to unite the functions of the five existing markets, namely Johar, Pedamaran, Beteng, Jurnatan, and Pekojan. The planned market sites include the Pedamaran market site, Johar Market, plus the prison house site, several shops, part of the Kanjengan courtyard, and part of the square. Below this picture (see figure 1) is a market activity that shows the booths as traditional markets. After 30 years of existence, there are more and more Johar Market traders. The market is no longer able to accommodate traders until most traders sell in traditional open spaces. (R. S. Rukayah \& Bharoto, 2012) In the 70s, to accommodate traders in this open space, the government built the Jaik market. Quantitative data has not been found with certainty when the market can no longer accommodate traders (1950s).

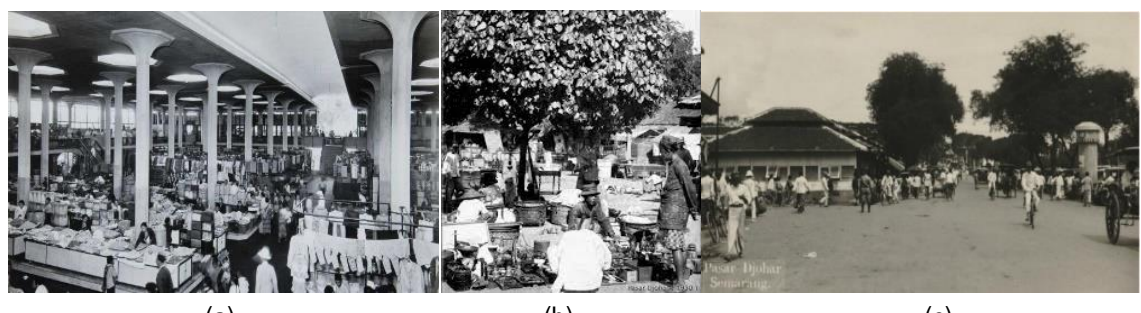

(a)

(b)

(c)

Figure 1: (a) Johar market after becoming modern. (b) the beginning of the market, traders are still under the Johar tree. (c) the early Johar market which is still a small booth on the street

(Source: KITLV)

\subsection{Modern Market in that Time}

Ir. H. Thomas Karsten, a Dutch architect, planned the Johar market as a modern traditional market with a distinctive construction, namely mushroom column technology, which is the center for shaping Semarang's identity and considering the tropical climate in Indonesia. In terms of architecture, the building with a roof similar to that of a mushroom is expected to function as an air vent that can save energy and prevent heat from the scorching sun by the entry of wind gusts from the ventilation. The upholstery for floors, walls, stairs, and stall tables is made of andesite, sturdy, and easy to clean. The construction of a mushroom column with a high ceiling can create the atmosphere in Johar Market Semarang still feels fresh. High ceilings ensure comfortable air circulation. Stone foundations, reinforced concrete structures, with a fungal system in the columns. The column has a 6 -meter module with an octagonal cross-section. Columns like this are called Jamur constructs (mushroom). 
When viewed from the Johar Market Entrance has two orientation directions. The Johar Market building's orientation faces Agus Salim Street, the location of the Johar Central area market. When viewed from the orientation towards the outer space of the surroundings, facing the traditional square. However, the main orientation of the Johar market building was initially towards the West or Alun-Alun/ traditional square, as time passes and modern developments, now the traditional square, the orientation of the Johar Market, is no longer there. Now the physical object of the building cannot be seen because it is covered by a new building in the form of the Jaik market building (R. S. Rukayah \& Bharoto, 2012) so when the current condition (before the fire) the orientation of Johar Market towards to $\mathrm{H}$. Agus Salim Street (north) whose road conditions are narrow because part of the road is used as an area for street vendors. Johar Market consists of two floors, with an atrium (courtyard) in the middle of the building and a mezzanine on edge around the room. Between the first and second floors are connected by stairs on all four sides, one ramp in Johar north and two ramps in Johar Central area (Brommer et al., 1995).

\subsection{Johar Market as a Cultural Heritage}

The current condition of Johar Market has just been burned, and of course, it must be restored because it is a cultural heritage. Based on Hendro (2015) Semarang City Government should have made strict rules and then socialized them, so the public knows it. Governments not only prohibit or regulate, but they can also provide great solutions (Panggabean, 2014). Johar Market, which is still under dispute, between conservation and commercial interests (Panggabean, 2014). Figure 2 shows the difference between the Johar market after it was revitalized (figure $2 b$ ) and before it was revitalized due to the fire (figure 2a). Unfortunately, the renovated buildings are still not occupied by traders. It is suspected that it was due to many traders, while the renovated buildings were only in the northern part.

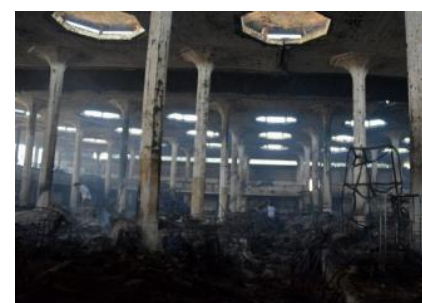

(a)

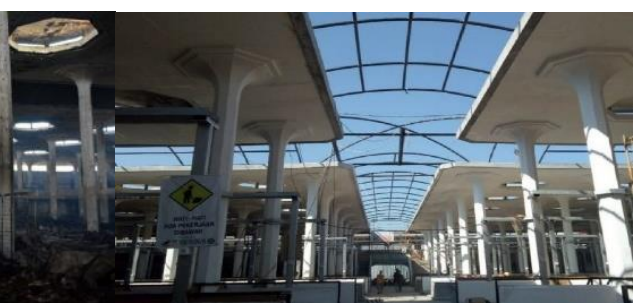

(b)

Figure. 2: (a) (right the condition of the Johar market after the 2015 fire tragedy; (b) The current condition of the Johar market after the Johar market renovation project.

(Source: (a) cnnindonesia.com (b) Deva's personal photo, Engineering staff in the Johar Market drainage project)

\subsection{Adaptive Reuse in Johar Market}

In 2019 the government, together with the ministry Pekerjaan Umum dan perumahan Rakyat (PUPR) / Ministry of Public Works and Public Housing, revitalized Johar Market 
(Kemenkeu, 2019), in the northern part of the building (see figures 3 and 4) and was completed in 2019 (Kementerian PUPR, 2019a). The PUPR Ministry is still trying to continue the revitalization until the central and southern Johar market building areas are completed (see figure 2). The revitalization carried out by the PUPR Ministry continues to prioritize the principles of preserving cultural heritage buildings by involving the Regional Government (Kementerian PUPR, 2019b) and applying the adaptive reuse concept, which is the best revitalization technique for bringing historical buildings to life (Garcia \& Ayuga, 2007).

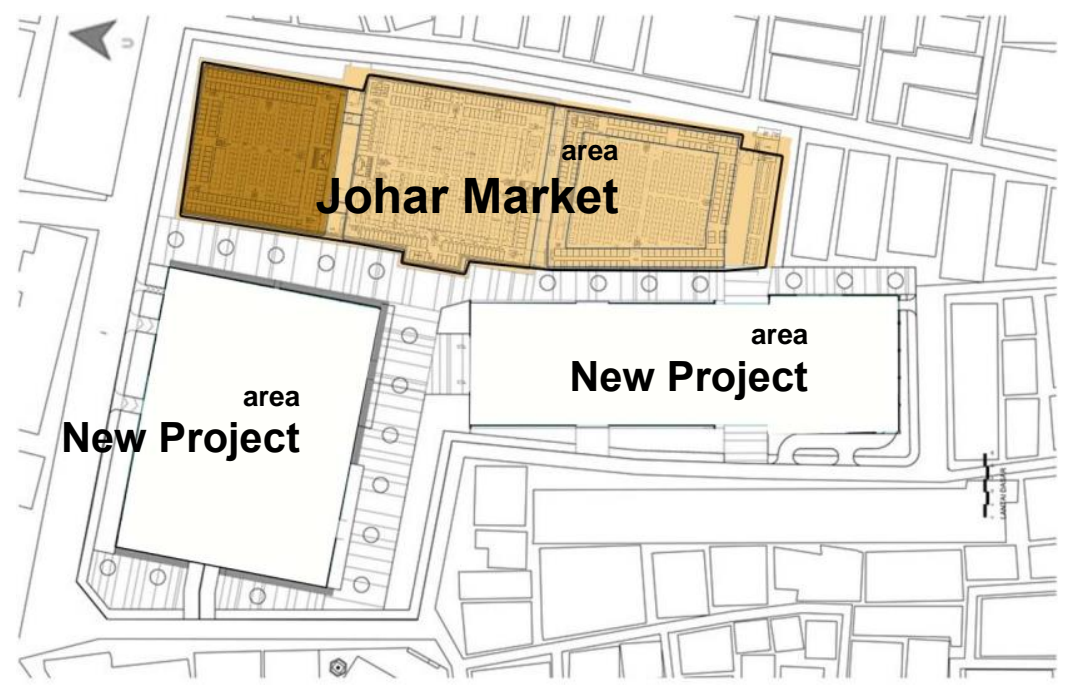

Figure. 3: Johar market location

(Source: Semarang City Planning and Housing Office, 2019)

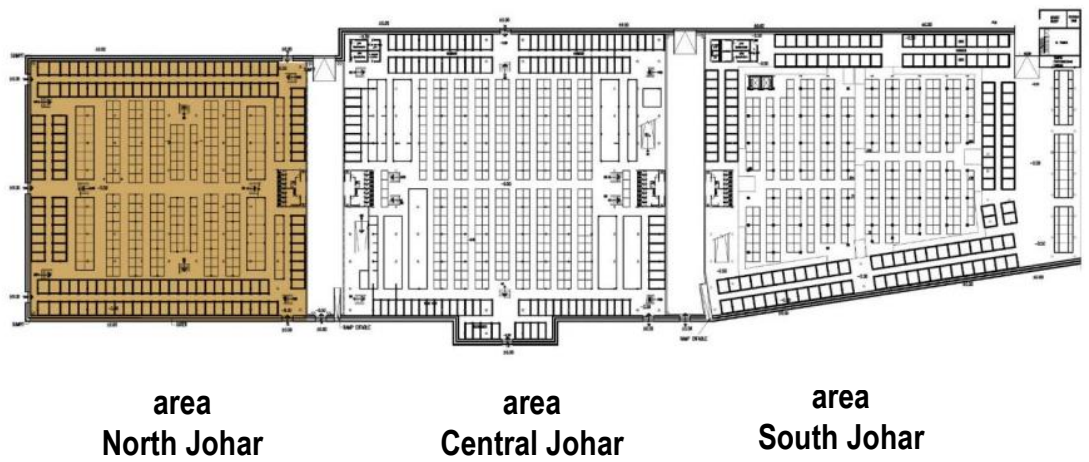

Figure. 4: The brown floor plan of Johar's market is the part of the Whole market that has been completely revitalized

(Source:Semarang City Planning and Housing Office, 2019) 
In the Johar market building, the adaptive reuse type used is the insertions type because the Johar Market construction and structural improvements are partially dismantling. The components are then reinforced. It can be seen in Figure 5 that the mushroom-like column is still used and utilized as the main structure in the building (see the comparison in Figures 5a and b). In Figure 5a, conditions in the Johar market in the north before the renovation, many of the stalls are irregular. Figure $5 b$ shows that after the revitalization is carried out, it is now equipped with stalls that traders can use directly. It's just that with this regularity, of course, not all traders will be able to return to selling in it.

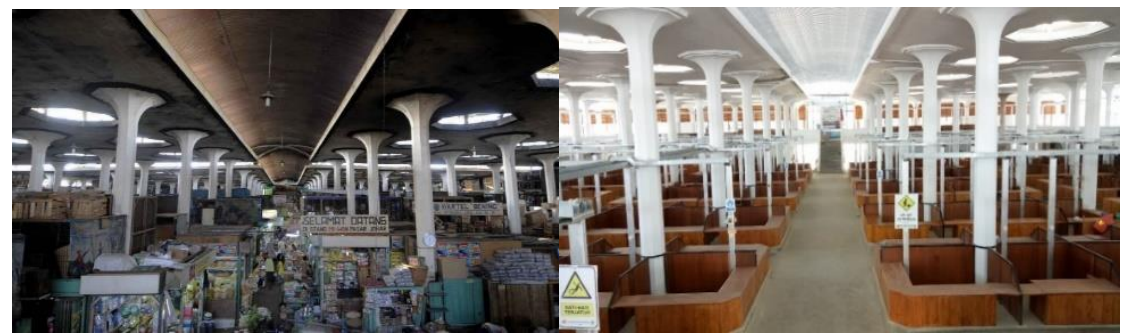

(a) (b)

Figure. 5: (a) Johar market before being revitalized; (b) Johar market after being revitalized

(Source: Ministry of Public Works and Public Housing, 2019)

Figure $5 b$ shows that adaptive reuse is a very effective and easy strategy in renovating the market and providing new functions that are still in line with the old ones. There is a slight drawback that some elements that have been replaced may reduce the authenticity of the building (The Hong Kong Institute of Architect, 2012).

\subsection{The Traders}

\subsubsection{In the Early Era of Johar Market}

During the Johar market era before, these traders initially traded in front of the prison to the east of the Semarang square. There were not as many traders as now because the traders served the prisoners' families waiting for visiting hours under a row of Johar trees. At that time, the location was not a building but an area in an open space shaded by several trees. Based on the records of Gemeenteblad uitggeven voor, the levy account is carried out every month or quarter by distributing cards, and for seasonal sellers, the levy is done every day. The levy is used for the benefit of traders. From the retribution, the government finally decided to build several booths, and the stalls were equipped with the number and name of the tenant (Wijayati, 2009). The cost of making these loods requires $f 1,800$ in cash, but this cost can be covered by collecting 240 permanent traders, by setting each person (Liem, 2004).

After the colonial government built it into a modern market, the Johar Market trading area had various economic activity characteristics because the area was a regional market 
area in Semarang City. These economic activities include trade and service activities (Muspriyanto, 2007). Trading activities consist of markets, street vendors, shops, and food stalls. Meanwhile, those covering the service sector include banking, hospitality, and warehousing. Until 1931, when the traders moved to the market building, the market activity was getting busier, and the number of traders grew.

However, the glory of the Johar market diminished in 2005, as a result of tidal flooding of 22.95 ha (Ramadhany et al., 2012), this makes resulted in a degradation of visitors and traders, resulting in this area no longer being a destination shopping center (Kurniawati \& Suwandono, 2015). This condition occurs because the market location is located in an area lower than the surrounding area. Tidal flooding was also increasing risk by the drainage conditions that were not functioning optimally so that the floodwaters were unable to flow into the drainage channels. (Kurniawati \& Suwandono, 2015).

\subsubsection{Post-Fire Traders}

Apart from the rob's condition, Johar Market also experienced a fire in 2015 so that the market could not be used. The traders, after the fire, were finally relocated to the Central Java Grand Mosque (MAJT) area on Jalan Arteri Soekarno-Hatta in Sambirejo Village, Gayamsari District Semarang. The government has also prepared temporary locations in several places such as Kanjengan Market, Rejosari Market, Bulu Market, etc. However, due to the large number of traders who were accommodated traders, the government finally did not determine the stalls on the protocol roads (Pasca-Kebakaran, Pedagang Johar Market Direlokasi Di Komplek Masjid Agung, 2015). It was recorded that before the relocation, 6,087 traders consisted of a combination of traders from eight markets, namely Johar Utara Market, Johar Tengah Market, Johar Selatan Market, Johar Shopping Center, Yaik Permai Market, Yaik Baru Market, Pungkuran Market, and Kanjengan Market. However, after the relocation, there was a decrease in traders, which currently only consist of 1,206 traders from Johar Market Utara, Johar Market Tengah, and Johar Market Selatan (Setiaji \& Fatuniah, 2018). The fire's impact was very significant because the conditions were not the same as usual in the previous market.

\subsection{Conclusion}

\section{Specifict traders for renovation Johar Market}

Based on the Johar market renovation plan pictures, the Johar market has not fully succeeded in revitalizing it because the market activities have not fully returned. The Johar market's total capacity now only accommodates around 4000 traders, far less than before, which can accommodate more than 6000 traders. The market capacity that has been rehabilitated is still insufficient, so it cannot accommodate all traders. This means that the number of old traders will not necessarily be accommodated in the renovated buildings.

Therefore, the concept of revitalization is only focused on revitalizing buildings, not revitalizing market activities. The presence of this new Johar market cannot restore the atmosphere as a traditional market. The modern conservation concept of the Johar market 
is only the concept of building conservation but has not adopted the idea of conservation of traditional trading activities.

\begin{tabular}{|c|c|c|c|}
\hline $\begin{array}{c}\text { The Johar market } \\
\text { was designed by } \\
\text { Thomas Karsten in } \\
1930 \text { to } \\
\text { accommodate a } \\
\text { total of } 240 \text { traders }\end{array}$ & $\begin{array}{l}\text { in 1950, the } \\
\text { number of traders } \\
\text { overflowed into the } \\
\text { market yard and } \\
\text { even into the } \\
\text { square area }\end{array}$ & $\begin{array}{l}\text { In } 2015 \text {, there was } \\
\text { a fire, traders } \\
\text { relocated around } \\
6,000 \text { traders, then } \\
\text { reduced by around } \\
1000-2000 \text { traders }\end{array}$ & $\begin{array}{l}\text { In } 2019 \text {, the } \\
\text { renovation of the } \\
\text { north, central and } \\
\text { south side of the } \\
\text { Johar market has } \\
\text { not been } \\
\text { completed, so } \\
\text { traders have not } \\
\text { been fully } \\
\text { accommodated }\end{array}$ \\
\hline
\end{tabular}

Figure 6: Process diagram from Johar Market

(Source: Author's Analysis)

Figure 6 describes the framework of events from the Johar market, from the beginning of development designed by Thomas Karsten to become a large market in the Southeast Asia region. In 2015 there was a big fire so that the government carried out a conservation project. In this project, which is carried out in some steps, it is impossible to include all traders in it. It should be noted in classifying traders because many traders cannot be accommodated in new buildings. It is necessary to classify several characteristics of the types of traders in traditional markets, for example, the classification of wet traders, vegetables, fruits, meat, and so on, then souvenirs, clothing, and stationery. The Johar market has the characteristics of traders, such as basics or street vendors, kiosks, and booths; according to (Saputra, 2016), The street vendors cannot be separated from cultural elements, and their existence cannot be eliminated, which means that street vendors and traders dominate the Johar market in the area under the road/floor who sell on several sides of the building to the shoulder of the road. These components of traders influence the existence of the market as traditional culture. Based on Karnajawa, (2002) market changes can also change land use, road patterns, movement, and building patterns or types. This is closely related to the behaviour in establishing relationships with these various relationships as a chain of success in trading (Sutami, 2012). This component is important to consider in conserving the Johar market as a whole. 


\subsection{Recommendations}

The Johar market's conservation is included in the adaptive reuse insertions category because it still uses the building facades and its main structure. The Thomas Karsten's design is maintained, especially the mushroom-shaped pillars and two-story buildings, the repair techniques will not disturb cultural heritage buildings' shape. This is good because it still retains the initial design and follows the rules of improving cultural heritage buildings. Insertions are commonly used to revitalize buildings, change the layout of the booths and kiosks, and add market support facilities. Adaptive reuse applied to the Johar market is the right strategy because it saves time and is economical. Because conservation has not covered the whole, traders cannot be accommodated. Conservation of the central and southern zones will only be implemented if there is funding from the central government. Therefore, the conservation of the building in the northern zone is still empty. The Johar market has the characteristics of traders, for example, basics or street vendors, kiosks, and booths. Types of traders are because of their shape; traders who can be included in the northern zone are traders of grocery, clothing, and souvenir types. The government should hold a discussion meeting with the traders about the demands and desires of the old traders to return to their activities because the traders want to return to using this Johar market. However, it requires new regulations from the government regarding merchant regulations to sell in it, including what types of merchandise occupy the new market. It is hoped that the construction of malls, supermarkets, or modern markets will not be close to the Johar Market area in the future so that there will be no worries for traders in selling their wares. The government needs to set up a particular container or prepare space that can be used for annual events such as dugderan so as not to interfere with access to the Johar market itself and cause traffic jams.

\section{Acknowledgement}

The researcher would like to thank PT Yodya Karya Semarang for providing data on the renovation of the Johar market development. This research is part of a research on ancient buildings and land subsidence funded by DIKTI Indonesia and NWO Worto the Netherlands No Contract: 257-91 / UN7.6.1 / PP / 2020

\section{References}

Adishakti, L. (2009). Tantangan kota pusaka indonesia. Kongres I Jaringan Kota Pusaka IndonesiaAt: Sawahlunto, Sumatera Barat, October 2009.

Australian ICOMOS Inc. (2012). The Burra Charter: The Australia ICOMOS Charter for Places of Cultural Significance. 1-10. https://doi.org/363,690994 ICO

BAPPEDA Kota Semarang. (2006). Senarai: inventarisasi dan dokumentasi bangunan dan kawasan pusaka budaya kota Semarang. Semarang: Bappeda Pemerintah Kota Semarang. 
Bollack, F. A. (2013). Old buildings, new forms: new directions in architectural transformations. Monacelli Press.

Brommer, B., Sidharta, A., Budihardjo, E., Siswanto, A., Montens, A. B., Soewarno, S. S., \& Stevens, T. (1995). Semarang, Beeld van een stad. Voorburg: Asia Maior.

Budihardjo, E. (1997). Tata ruang perkotaan. Penerbit Alumni.

Bullen, P., \& Love, P. (2011). Factors influencing the adaptive re-use of buildings. Journal of Engineering, Design and Technology, 9(1), 32-46.

Ercan, M. A. (2016). Creating Sustainable Communities In Historical Heritage Sites : Istanbul 'S Historic Creating Sustainable Communities In Historical Heritage Sites: Istanbul' S Historic Neighbourhoods. 3630(April). https://doi.org/10.1179/sic.2010.55.Supplement-2.237

Garcia, A. I., \& Ayuga, F. (2007). Reuse of abandoned buildings and the rural landscape: The situation in Spain. Transactions of the ASABE, 50(4), 1383-1394.

Hendro, E. P. (2015). Pelestarian Kawasan Konservasi di Kota Semarang. Pelestarian Kawasan Konservasi Di Kota Semarang, 17-28.

Jang, M., Park, S. H., \& Lee, M. H. (2017). Conservation management of historical assets through community involvement a case study of Kanazawa Machiya in Japan. Journal of Asian Architecture and Building Engineering, 16(1), 53-60. https://doi.org/10.3130/jaabe.16.53

Karnajawa, S. (2002). Pengaruh Pemindahan Lokasi Market Terhadap Morfologi Kota Studi Kasus: Kota Cepu Kabupaten Blora. Program Pasca Sarjana Universitas Diponegoro.

kemenkeu. (2019). Revitalisasi Market Johar Semarang, Bangun Optimisme Jelang Tahun 2020.

Kementerian PUPR. (2019a). Kementerian PUPR Rampungkan Revitalisasi Market Johar dan Siap Ditempati Pedagang.

Kementerian PUPR. (2019b). Presiden Jokowi Tugaskan Kementerian PUPR Lanjutkan Revitalisasi Market Johar di Bagian Selatan.

Kurniawati, W., \& Suwandono, D. (2015). Pengaruh Bencana Banjir dan Rob Terhadap Ketahanan Ekonomi Kawasan Perdagangan Johar di Kota Semarang. Ruang, 1(4), 261. https://doi.org/10.14710/ruang.1.4.261-270

Latham, D. (2016). Creative Reuse of Buildings: Volume One. Routledge.

Liem, T. J. (2004). Riwayat Semarang. Semarang: Hasta Wahana.

Luo, Y., \& Qi, L. (2019). Construction and practice of a conservation plan implementation evaluation system for historic villages. Journal of Asian Architecture and Building Engineering, 18(4), 351-361. https://doi.org/10.1080/13467581.2019.1661843

Luo, Y., \& Qi, L. (2020). Evaluation of implementation and operation mode of conservation planning of historic villages in the Pearl River Delta. Journal of Asian Architecture and Building Engineering, 19(4), 327-340. https://doi.org/10.1080/13467581.2020.1748039

Mengembalikan Identitas Kota Pusaka. (2015). In Buletin Ciptakarya. Kementerian Pekerjaan Umum dan Perumahan Rakyat. Muspriyanto, E. (2007). Semarang Tempoe Doeloe: Meretas Masa. Semarang: Terang Publishing. Permadi. 
Musso, S. F., \& Loughlin, K. (2011). Conservation / Transformation.

Panggabean, S. A. (2014). Perubahan Fungsi Dan Struktur Bangunan Cagar Budaya Kota Semarang Ditinjau Dari Perspektif Undang-Undang Nomor 11 Tahun 2010. Unnes Law Journal, 3(2), 24-34.

Pasca-Kebakaran, Pedagang Market Johar Direlokasi di Komplek Masjid Agung. (2015). Tribun Jogja.

Pongsermpol, C., \& Upala, P. (2018). Impacts of Adaptive Reuse of Heritage Buildings Converted to Small Hotels in Bangkok. Asian Journal of Quality of Life, 3(13), 69-79. https://doi.org/10.21834/ajqol.v3i13.163

Ramadhany, A. S., Subardjo, P., \& Suryo, A. A. D. (2012). Daerah Rawan Genangan Rob di Wilayah Semarang. Journal of Marine Research, 1(2), 174-180.

Rukayah, R. S., \& Abdullah, M. (2019). The Glory of Semarang Coastal City In The Past , Multy - Ethnic Merchants And Dutch Commerce. Journal of Southwest Jiaotong University, 54(6).

Rukayah, R. S., \& Bharoto. (2012). Bazaar in Urban Open Space as Contain and Container Case study: Alunalun Lama and Simpang Lima Semarang, Central Java, Indonesia. Procedia - Social and Behavioral Sciences, 50(July), 741-755. https://doi.org/10.1016/j.sbspro.2012.08.077

Rukayah, R. S., \& Malik, A. (2012). Between Colonial, Moslem, and Post-Independence Era, Which Layer of Urban Patterns should be Conserved? Procedia - Social and Behavioral Sciences, 68, 775-789. https://doi.org/10.1016/j.sbspro.2012.12.266

Rukayah, S., \& Supriadi, B. (2017). Market Di Sudut Tiga Koridor Lama Semarang Sebagai Pembentuk Place Dan Lingkage Ekonomi,. Tataloka, 19(2), 82-92. https://doi.org/10.14710/tataloka.19.2.\%p

Saputra, R. B. (2016). Profil Pedagang Kaki Lima (Pkl) Yang Berjualan Di Badan Jalan (Studi Di Jalan Teratai Dan Jalan Seroja Kecamatan Senapelan). Jurusan Sosiologi Fakultas IImu Sosial Dan Politik Universitas Riau, 53(9), 1689-1699. https://doi.org/10.1017/CBO9781107415324.004

Setiaji, K., \& Fatuniah, A. L. (2018). Pengaruh Modal, Lama Usaha dan Lokasi Terhadap Pendapatan Pedagang Market Pasca Relokasi. Jurnal Pendidikan Ekonomi Dan Bisnis (JPEB), 6(1), 1-14. https://doi.org/10.21009/jpeb.006.1.1

Sutami, W. D. (2012). Strategi Rasional Pedagang Market Tradisional. Jurnal Biokultur, 1(2), 127-148. http://www.journal.unair.ac.id/filerPDF/03 Wahyu Dwi S---Strategi pedagang market tradisional.pdf

The Hong Kong Institute of Architect. (2012). Hong Kong Today: Conservation \& Revitalization of Historic Buildings. In The Hong Kong Institute of Architect. file:///C:/Users/USER/Desktop/LS08_Conservation and Revitalization of Historic Buildings_Teaching notes.pdf

Tjandra, R. (2019). Kajian Sistem Arsitektur Pada Market Johar Semarang Karya Thomas Karsten. Universitas Katolik Soegijapranata.

Wang, C. H., \& Fu, C. C. (2014). Dynamic and diverse conservation approaches for an historical irrigation system: A cultural landscape in Taiwan. Journal of Asian Architecture and Building Engineering, 13(1), 25-32. https://doi.org/10.3130/jaabe.13.25

Wijayati, P. A. (2009). Eksistensi Market-Market Tradisional Di Kota Semarang Tahun 1873 - 1914 Putri Agus Wijayati Jurusan Pendidikan Sejarah FIS Unnes. Jurusan Pendidikan Sejarah FIS Unnes, 36(380), 167-183. 
Yung, E. H. K., \& Chan, E. H. W. (2012). Implementation challenges to the adaptive reuse of heritage buildings: Towards the goals of sustainable, low carbon cities. Habitat International, 36(3), 352-361.

Zonta, D., Pozzi, M., \& Zanon, P. (2008). Managing the historical heritage using distributed technologies. International Journal of Architectural Heritage, 2(3), 200-225. https://doi.org/10.1080/15583050802063691 